\title{
Actualistic Zooarchaeology in Central Western Argentina in Cave and Open Air Contexts
}

\author{
Clara Otaola
}

Author address: Museo de Historia Natural de San Rafael. Av Ballofett s/n Parque Mariano Moreno. C.P: 5600, San Rafael, Mendoza, Argentina.

Email: claraotaola@yahoo.com.ar

Received: July 8, 2014

Volume: 5:94-103

Published: September 4, 2014

(C) 2014 Society of Ethnobiology

\begin{abstract}
Many cultural and natural processes form the archaeological record. Taphonomy, the study of the transition of organic matter from living contexts (the biosphere) to geological contexts (the lithosphere), aids in understanding how agents and processes affect skeletal remains in the archaeological record. In this paper the results of an actualistic taphonomic study on deposition of bones in open-air and cave contexts in the high elevation Andes Mountains are presented. Results indicate that within the first three months after deposition many bones are displaced or removed from sites and that the agents that act in each context are different. Horizontal displacement of bones from their deposited locations is limited in the cave context but is dominant in the open air site. Carnivores appear to be responsible for moving bones in open-air contexts, and rodents appear to displace bones vertically in the cave context. Such naturalistic experiments are important in particular areas of the world in which local taphonomic processes vary.
\end{abstract}

Keywords: Actualistic research; Taphonomy; Zooarchaeology; Carnivore damage; Rodent damage

\section{Introduction}

For nearly two decades archaeologists have recognized a need for development of actualistic taphonomic research in central, western Argentina (Borrero 2002; Gil 2006; Neme 2007; Neme et al. 1995; Neme et al. 1999; Neme and Gil 2008). Several zooarchaeological studies that focus on differential preservation of animal remains and agents of bone destruction have been published during the last five years that help fill this gap (Corbat et al. 2009; Fernández 2012; Giardina 2010; Otaola et al. 2012). However, none of the studies report results from actualistic experiments that characterize processes and agents within the context of regional environmental conditions.

The archaeological record contains material products related to human activities that occurred in the past. These materials are invariably exposed to an array of processes from the time they were discarded to the time they are recovered and investigated by archaeologists. Zooarchaeology focuses on the portion of the archaeological record that comprises animal remains (e.g., remnants of bones, teeth, horn, antler, shell, and other biological residues from animals) that are recovered from archaeological sites. Within zooarchaeology, taphonomy is the study of peri- and post-mortem events that affect remains of animals in the passage from the biosphere to the lithosphere, including diagenetic processes (Efremov 1940; Olson 1980). These processes make up the taphonomic history (Lyman 1994) of faunas, which are assemblages of animal remains from a particular spatial and temporal context. It is important to understand how these processes influence the condition (e.g., shape, completeness, identifiability) of animal remains because bone, shell, antler, horn, and other types of remains can be added to, removed from, or modified within any particular assemblage during its taphonomic history. In order to understand past human behaviors related to subsistence and human ecology, it is important to understand the taphonomic histories of zooarchaeological assemblages.

Taphonomic analysis relies on the use of analogies to make inferences about taphonomic histories of faunas. In some cases, these analogies are based on actualistic studies in which agents and processes that cause signatures (effects) are observed; this type of analogy is termed a relational analogy (GiffordGonzalez 1991; Hodder 1982). For example, in Haynes' (1980) research on carnivore damage on 
skeletal remains, analogies are based on observation of carnivores ravaging bones, from which characterizations of gnawmarks were made. Recognition of carnivore damage on bones from archaeological contexts is made by relational analogy because similar processes (gnawing) are inferred to have led to similar effect (gnawmarks). Formal analogies are a weaker type of analogy that simply attribute similar cause to similar attributes without observation of the processes that led to the effects (Gifford-González 1991). Actualistic studies provide a means to develop relational analogies; taphonomists develop studies for assessing different manners in which diverse agents influence (preserve, move, damage) bone, which then aid in the construction of taphonomic histories of faunas. Relational analogies rest on the principle of methodological uniformitarianism, where it is assumed that natural laws do not vary with time; therefore processes observed in the present are the same as those that occurred in the past (Simpson 1970).

There are two kinds of actualistic studies: naturalistic studies and controlled experiments (Marean 1995). The main difference between these is that in experiments, the analyst controls variables to precisely understand the relations between the trace (effects on remains) and the agent that generates it. Taphonomic experiments can be performed in a laboratory or with animals in captivity, but can also be done in natural settings (Blumenschine and Marean 1993). In such cases, the researcher controls and manipulates the variables of interest, in order to refine understanding of the process being studied. In contrast, in naturalistic studies the analyst does not manipulate the parameters of the process being studied, since those processes occur in a natural context. A classic example is Behrensmeyer's (1978) naturalistic studies on bone weathering in which bone was exposed to natural weathering agents for which stages were described. The strength of experiments is precise control of taphonomic variables, but a weakness is that experiments do not occur in realistic contexts. Naturalistic studies, in contrast, benefit from being carried out in realistic contexts but allow less precise control of taphonomic variables.

In this paper, I present two naturalistic studies carried out in southwestern Mendoza Province, Argentina, in the central basin of the Salado River, in the Andes Cordillera (Figure 1).

In this area, archaeological research had been carried out for more than twenty years. Zooarchaeological remains that are recovered from sites are highly fragmented and preservation is poor. Several processes affect these faunal assemblages during their taphonomic histories, and the aim of this study is to understand the processes that influenced bones during the initial stages after their discard and deposition. The focus of this research is on the agents that impact bones from goat (Capra bircus) carcasses immediately after deposition in the high altitude environment of the Andes. Although goats were introduced during the historic period, this study focuses on those processes that influence ungulate skeletons and bone in general.

The area is located in the Patagonia physiographic province (Cabrera 1971), zoogeographically this region corresponds to the Fauna de Montaña, consisting of mammals such as Puma concolor and Lama guanicoe, Lycalopex culpaeus, Dolichotis patagonum, Lagidium viscacha, Microcvia australis, Akodon andinus and Phyllotis darwini migratory birds that live in small lagoons and creeks (e.g., Anas sp. and Choelephaga picta) as well as scavengers birds, such as Vultur griphus, Caracara plancus and Milvago chimango (Roig 1972).

\section{Methodology}

Experiments were done in two locations and replicated in two sequential years; January 2009 and January 2010. The different locations were labeled "Context A" and "Context B". Context A study was in an openair site, and Context B was located in a small cave (Figure 1, A and B). Context A is $150 \mathrm{~m}$ from $\mathrm{El}$ Desecho creek, at $35^{\circ} 11^{\prime} 56.2^{\prime \prime}$ south latitude and $70^{\circ}$ 03' 49.3" west longitude, at 2082 masl. The cave selected for doing these experiments (Context B) is located $1100 \mathrm{~m}$ from the Context $\mathrm{A}$, near Colorado Creek, at $35^{\circ} 12^{\prime}$ 03.4" south latitude and $70^{\circ}$ 5' 25.6" west longitude, at 2200 masl. The cave has a depth of $5.5 \mathrm{~m}$ and a width of $4.8 \mathrm{~m}$. Both contexts have archaeological materials on the surface. Indeed, Context B is located within the Cueva Arroyo Colorado archaeological site, which had been excavated and reported previously (Lagiglia et al. 1994; Neme 2007).

Defleshed goat bones were deposited on the surface and at $20 \mathrm{~cm}$ depth below surface in both contexts. Bones were registered and photographed in their locations of deposition; after three months the bones were located, recovered, and studied in the laboratory. In January 2009, a total of 48 skeletal elements from a single goat carcass were deposited in Context A. Thirty-six of these bones were left at the 
Table 1. Bones deposited in Context A and the assemblage found three months after this deposition. First experiment (2009) and replication (2010).

\begin{tabular}{|c|c|c|c|c|c|}
\hline \multirow{3}{*}{ 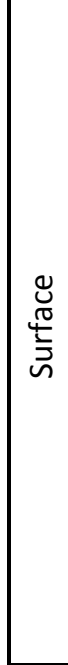 } & \multirow[b]{2}{*}{$\begin{array}{l}\text { GOAT (Capra hircus) } \\
\text { ELEMENT }\end{array}$} & \multicolumn{2}{|l|}{ Start } & \multicolumn{2}{|c|}{ End (Three months later) } \\
\hline & & NISP & Obs. & NISP & Bone modifications/Observations \\
\hline & $\begin{array}{l}\text { Ribs } \\
2 \text { Metapodials with } 1^{\circ}, 2^{\circ} \\
\text { and } 3^{\circ} \text { phalanx } \\
\text { Humerus } \\
\text { Scapula } \\
\text { Radius } \\
\text { Tibia } \\
\text { Proximal Femur } \\
\text { Innominate } \\
\text { Thoraxic vertebrae } \\
\text { Calcaneous } \\
\text { Astragalus }\end{array}$ & $\begin{array}{c}6 \\
8 \\
1 \\
1 \\
1 \\
1 \\
1 \\
1 \\
14 \\
1 \\
1 \\
\end{array}$ & Articulated & $\begin{array}{c}4 \\
2 \\
1 \\
1 \\
- \\
- \\
- \\
- \\
14 \\
1 \\
1 \\
\end{array}$ & $\begin{array}{l}\text { Moved from the original setting } \\
\text { Rodent marks, moved from the original setting under } \\
\text { the bush } \\
\text { Moved under the bush } \\
\text { Moved under the bush. Rodent marcs } \\
\text { - } \\
\text { - } \\
\text { - } \\
\text { - } \\
\text { Remain articulated. Under the bush } \\
\text { - } \\
\text { - }\end{array}$ \\
\hline 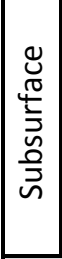 & $\begin{array}{l}\text { Scapula } \\
\text { Radius ulna } \\
\text { Thoracic vertebrae } \\
\text { Tibia } \\
\text { Metatarsal with } 1^{\circ}, 2^{\circ} \text { and } \\
3^{\circ} \text { pha. }\end{array}$ & $\begin{array}{l}1 \\
1 \\
7 \\
1 \\
8\end{array}$ & $\begin{array}{l}\text { Articulated } \\
\text { Articulated }\end{array}$ & $\begin{array}{l}1 \\
1 \\
7 \\
1 \\
2\end{array}$ & $\begin{array}{l}\text { Buried } \\
\text { Buried } \\
\text { Partially unburied. Gnawed } \\
\text { Buried } \\
\text { Buried }\end{array}$ \\
\hline \multicolumn{6}{|c|}{ Replication (Summer 2010) } \\
\hline 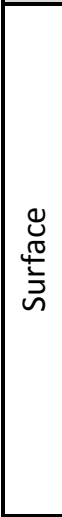 & $\begin{array}{l}\text { Innominate } \\
\text { Lumbar vertebrae } \\
\text { Tibia, radius, ulna } \\
\text { Femur } \\
\text { Ribs } \\
\text { Atlas } \\
\text { Axis } \\
\text { Cervical vertebrae } \\
\text { Scapula } \\
\text { Ribs calcaneus and } \\
\text { Tibia, } \\
\text { astragalus }\end{array}$ & $\begin{array}{c}1 \\
3 \\
3 \\
1 \\
6 \\
1 \\
1 \\
4 \\
1 \\
12 \\
3\end{array}$ & $\begin{array}{l}\text { Articualted } \\
\text { Articulated }\end{array}$ & $\begin{array}{l}2 \\
- \\
- \\
2 \\
4 \\
- \\
- \\
- \\
1 \\
- \\
2\end{array}$ & $\begin{array}{l}\text { Carnivore Marks. Perforations. } \\
\text { Carnivore marks - under the bush } \\
\text { Marks indet } \\
\text { Under the east part of the bush. } \\
\text { Under the bush. The calcaneus was absent. Tibia have } \\
\text { helicoidal fracture. }\end{array}$ \\
\hline 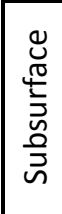 & $\begin{array}{l}\text { Femur } \\
\text { Scapula } \\
\text { Ribs } \\
\text { Innominate } \\
\text { Cervical vertebrae }\end{array}$ & $\begin{array}{l}1 \\
1 \\
5 \\
1 \\
4\end{array}$ & & $\begin{array}{l}1 \\
1 \\
5 \\
1 \\
4\end{array}$ & $\begin{array}{l}\text { Unburied } \\
\text { Unburied }\end{array}$ \\
\hline
\end{tabular}

surface near a Chuquiraga sp. bush, and 18 were buried $1 \mathrm{~m}$ east the surface assemblage. In Context B a total of 80 goat bones were deposited, 60 were deposited on the surface and 20 were buried near the east wall of the cave, $1 \mathrm{~m}$ from the cave entrance (Table 1 and 2).

After three months visible bones were mapped in Context $\mathrm{A}$ and $\mathrm{B}$, and it was noted if bones had been displaced, buried, or unburied relative to their original deposited locations. After recording, bones were recovered and analyzed for taphonomic modifications in the Department of Anthropology at the Museo de Historia Natural de San Rafael. Post-depositional modifications to bone surface, such as carnivore and rodent gnawmarks or any other agent responsible for bone-surface damage or fragmentation were recorded. 

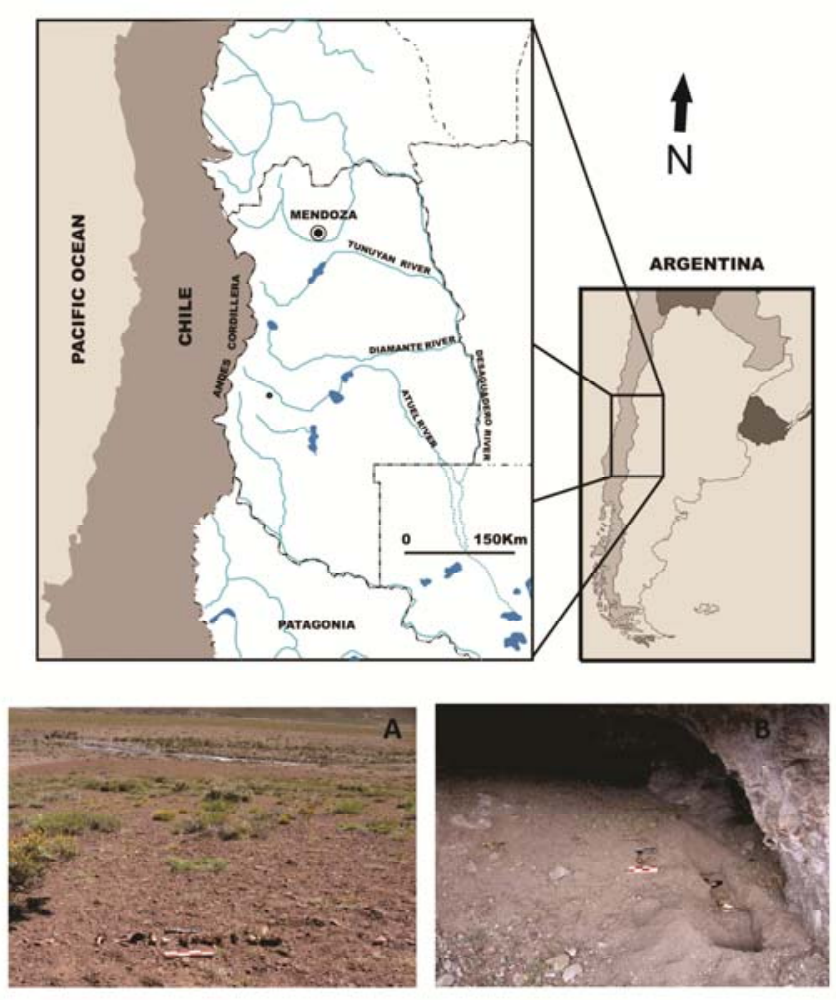

Figure 1. Localization of the actualistic studies presented in this paper. $A$ : context $A$; $B$ : context $B$.

The same three-month-duration experiment was replicated beginning in January 2010 in both contexts. In the replication, initial conditions from 2009 were maintained, such as use of goat bones, locations of deposition, starting-period for the experiment (January), and the same interval between initial deposition and subsequent observation (three months). In Context A for the replication a total of 48 bone elements were deposited, 36 on surface and 12 bones were left in subsurface. In Context B 69 bone elements were deposited on the surface and no bones were buried (Tables 1 and 2).

\section{Results}

After three months in Context A and B, skeletal elements were displaced from their original locations, were modified, or were missing altogether. Postdepositional displacement and modification are recorded in Table 1 for Context A and in Table 2 for Context B. In the first experiment (2009) of the 48 bones that were originally deposited in Context A, $60 \%$ were visible and recovered three months later. In the replication of this experiment, only $30 \%$ from a total of 36 bones were recovered. Most of the bones were displaced from their original deposition location and were trapped under a Chuquiraga sp. bush; some of the displaced bone exhibited carnivore marks indicating that perhaps a small carnivore cached the bones near the bush.

For buried bones in Context A, lumbar vertebrae were "emerging" at the surface, exhibiting carnivore gnawmarks and some evidence of pitting (Binford 1981; Haynes 1983, Lyman 1994), indicating that a small carnivore excavated the remains (Figure 2a). In the replication of this experiment, one buried femur and one buried innominate were recovered at the surface and exhibited carnivore damage (Figure 2b). In Context B for 2009 , only $46 \%$ of the specimens were recovered after three months, and in the replication in 2010 only $37 \%$ were recovered. None of the bones deposited on the surface were in their original positions. All of the bones that were buried in Context B were recovered near their original place of deposition.

Many bones recovered from Context A were damaged by carnivore ganwing. In the 2009 experiment, $28 \%$ of the bones exhibited carnivore gnawmarks and $8 \%$ of them showed rodent gnawmarks. In the 2010 replication, carnivore damage was recorded for $45 \%$ of the bones. Bones had been displaced under the Chuquiraga bush, all of them exhibiting pits or gnawmarks. One of the recovered tibiae exhibited a helicoidal fracture, similar to those made to extract medular grease (Binford 1981; Gifford-González 1989).

In Context B, carnivores and rodents also modified bones, though rodents were a more active agent in this context (Figure 2c and d). All the elements found at the end of the first replication have rodent marks and 3.5\% exhibit carnivore damage. In the 2010 replication, $84 \%$ of the bones were rodent damaged and 3.8\% exhibited carnivore gnawmarks (Table 2). Some bones had a combination of gnawmarks, pitting, and cupping, and some bones exhibited complete destruction of spongy bone, which is likely due to carnivore ravaging. Results of actualistic experiments in fox dens (Lycalopex culpaeus and $L$. griseus) in northwestern Argentina and Patagonia show patterns of damage like those observed here, not only destruction of the epiphyses, but also pitting and cupping on ends of the epiphyses (Fernández et al. 2010; Martin 1998; Mondini 1995, 2003a and b).

\section{Comparisons Between the Two Contexts}

Variables analyzed in this short term study provide 
Table 2. Bones deposited in Context B and the assemblage found three months after this deposition. First experiment (2009) and replication (2010).

\begin{tabular}{|c|c|c|c|c|c|}
\hline & GOAT & Start & & End $(t$ & e months later) \\
\hline & ELEMENT & NISP & Observations & NISP & Bone modifications/Observations \\
\hline & Tibia & 2 & Distal frag. (1) & 1 & Rodent marks \\
\hline & Ribs & 16 & & 3 & Indeterminate marks. Found in a den \\
\hline & Ulna & 1 & & 1 & Carnivore marks. Fracture \\
\hline & Femur & 2 & Distal frag. (1) & - & Rodent marks \\
\hline & Astragalus & 1 & & - & \\
\hline & Matapodial & 3 & Articulated & 3 & Rodent marks \\
\hline$\underset{\widetilde{\sigma}}{\tilde{\sigma}}$ & $1^{\circ}$ Phalanx & 6 & Articulated & 6 & Rodent marks \\
\hline 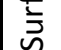 & $2^{\circ}$ Phalanx & 6 & Articulated & 6 & Rodent marks \\
\hline & $3^{\circ}$ Phalanx & 6 & Articulated & 6 & Rodent marks \\
\hline & Thoracic V. & 5 & & - & \\
\hline & Lumbar V. & 1 & & - & \\
\hline & Caudal V. & 2 & & - & \\
\hline & Scapula & 1 & & 1 & Rodent marks \\
\hline & Humerus & 1 & & - & \\
\hline & Innominate & 1 & & - & \\
\hline & Cervical V. & 1 & & - & \\
\hline & Radius UIna & 1 & & - & \\
\hline & Metapodial & 1 & Articulated & 1 & Buried \\
\hline & $1^{\circ}$ Phalanx & 2 & Articulated & 2 & Buried \\
\hline & $2^{\circ}$ Phalanx & 2 & Articulated & 2 & Buried \\
\hline ভ్ & $3^{\circ}$ Phalanx & 2 & Articulated & 2 & Buried \\
\hline$\stackrel{\frac{\pi}{5}}{\frac{1}{3}}$ & Radius & 1 & & 1 & Buried \\
\hline 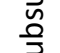 & Scapula & 1 & & 1 & Buried \\
\hline 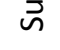 & Calcaneus & 1 & & 1 & Buried \\
\hline & Astragalus & 1 & & 1 & Buried \\
\hline & Ribs & 6 & & 6 & Buried \\
\hline & Cervical V. & 3 & & 3 & Buried \\
\hline & & & & Sumn & 2010 \\
\hline & Tibia & 2 & & 1 & Rodent marks \\
\hline & Astragalus & 1 & & - & \\
\hline & Calcaneus & 2 & & - & \\
\hline & Scapula & 2 & & 2 & Rodent marks \\
\hline & Innominate & 2 & & 2 & Rodemt marks \\
\hline & Femur & 2 & & 2 & Rodent marks (1) \\
\hline & Ribs & 26 & & 10 & Fragmented (2) Rodent(8) \\
\hline$\underset{\widetilde{J}}{\mathbb{J}}$ & Lumbar V. & 12 & & - & \\
\hline$\stackrel{4}{5}$ & Radioulna & 2 & & 2 & Carnivore (1) Rodent (1) \\
\hline & Cervical V & 3 & & 1 & Rodent \\
\hline & Axis & 1 & & - & \\
\hline & Atlas & 1 & & - & \\
\hline & Vertebrae & 3 & & - & \\
\hline & Caudal V. & 2 & & - & \\
\hline & Humerus & 1 & & 2 & Ro/Carn? Liquens (1) Rodent (1) \\
\hline & Thoracic V & 7 & & 4 & Rodent marks \\
\hline
\end{tabular}



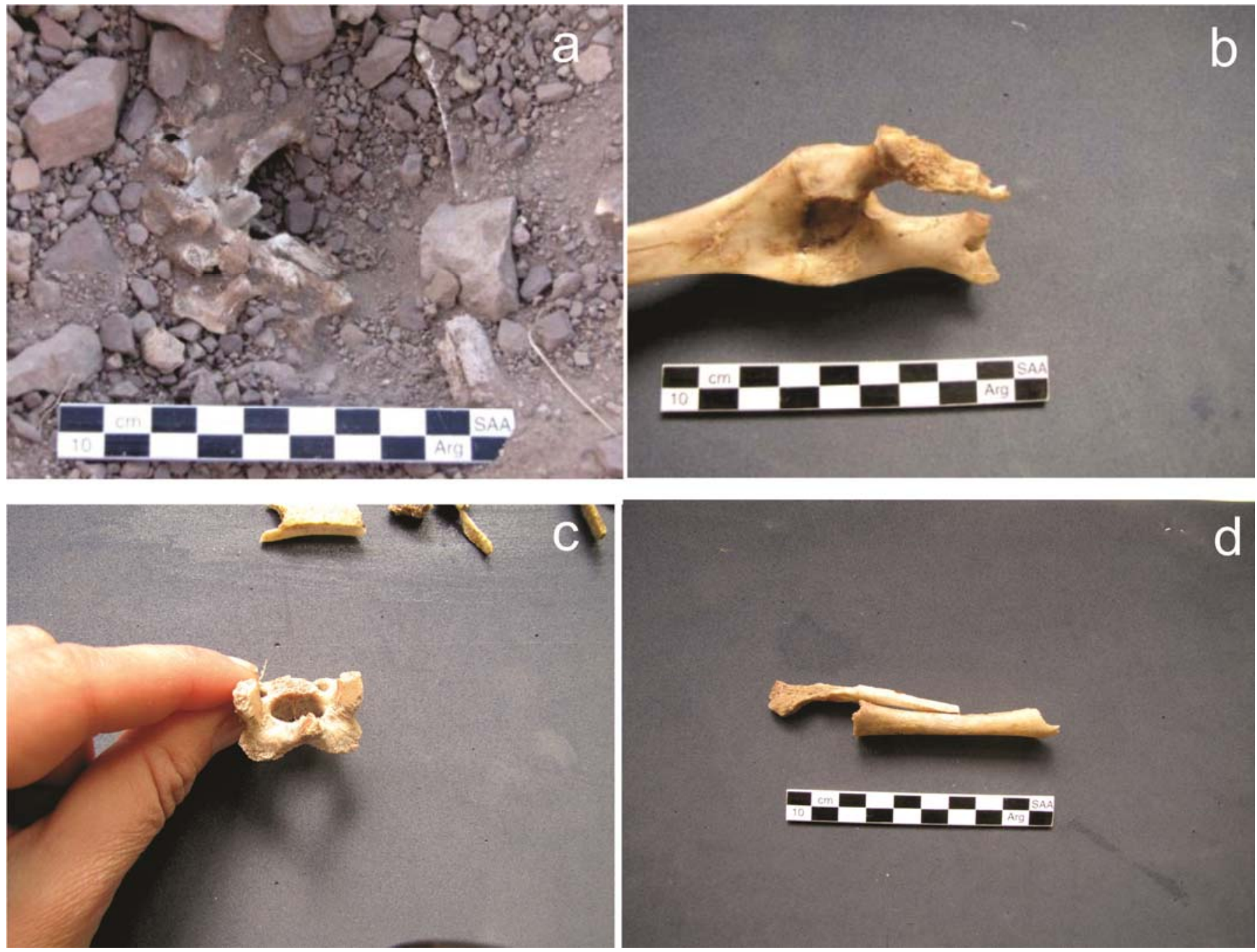

Figure 2. Different post-depositional damage. a \& b: carnivore gnawing in context A; c \& d: rodent gnawing in context B.

data on bone modification that occurs in the first three months after deposition of skeletal remains. This actualistic study is useful because it allows detection of differences and similarities in how taphonomic processes affect skeletal remains in the two different contexts, an open-air site and a cave, within the same physiographic region.

Surface assemblages of skeletal remains from Contexts A and B showed a substantial loss of skeletal elements after three months, illustrating that the potential for disappearance of unburied faunal remains is high in caves and open air sites in this region (Figure 3a and b).

Gnawing damage to bone is important in both contexts, but there are important differences regarding the agents involved. In the open air context (Context A), carnivores were the main agent responsi- ble for bone-surface modifications, and very few bones were gnawed by rodents (Figure 3c). In contrast, the rodents produced most of the gnawing damage in the cave context (Context B) (Figure 3d). Even though the common damages on bones generated by scavenger activity of birds such as Vultur gryphus (Andean condor), Coragyps atratus (black vulture), were not observed (e.g., digestive corrosion on bones and/or the presence of pellets), avian scavengers could be responsible for the displacement and disappearance of some bones in open air context. These processes were not observed in this study and remain a topic for future study.

In both contexts, skeletal remains were commonly displaced from their original location of deposition. However, horizontal and vertical dispersion of bones differ according to context. Vertical displacement is common in caves, due to restricted horizontal space 


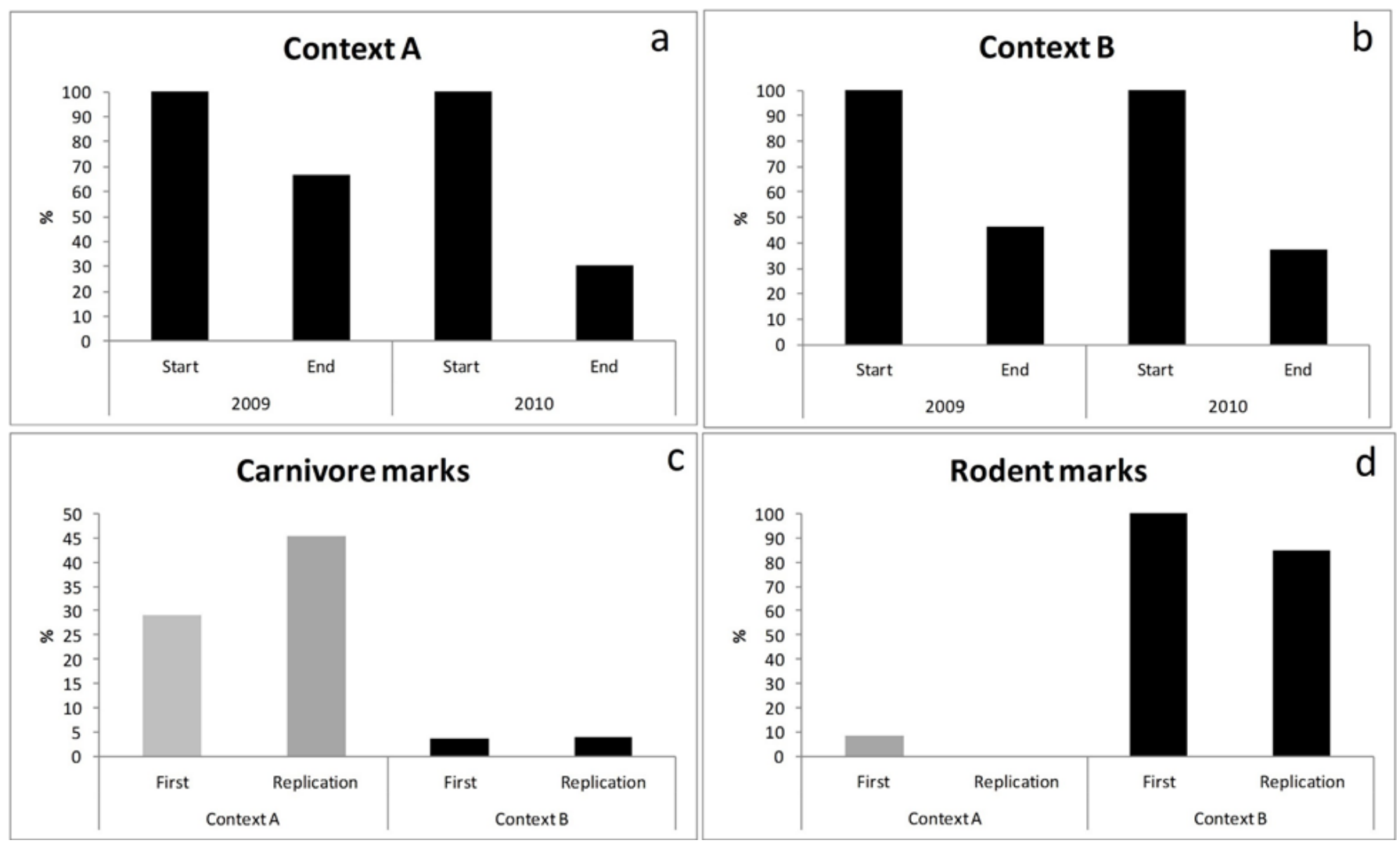

Figure 3. Comparison between context $A$ and $B$. a \& b: differences in NISP percentages at the starting of the experiment and at the end. c: carnivore marks in context $A \& B$, d: rodent marks in context A \& B.

and the high activity of fossorial animals that tend to live there. Signs of rodent activity (e.g., krotovina and rodent gnawmarks on bone) are common in cave archaeological assemblages. Indeed, many actualistic studies have been carried out in order to understand the impact of rodent disturbance on archaeological assemblages (Boceck 1986; Durán 1991; Erlandson 1984). In the open air context, even though some vertical displacement was observed in this study, horizontal displacement was more evident than vertical displacement. However, some bones in the open air site were vertically displaced. In Context A some of the bones that were originally buried, were removed by carnivores and recovered on the surface. In addition, there is limited evidence of horizontal displacement in Context B, as some of the remains were found in the rocky part of the cave, at a higher elevation than where they were originally deposited.

\section{Final Remarks}

The objective of this research is to understand agents involved in the modification of zooarchaeological assemblages in the Salado River Valley, in the Andean portion of Southern Mendoza. In this actualistic and naturalistic study (sensu Marean 1995), initial variables were controlled (such as locations of deposition), but there was not strict control of what happened after deposition. Given these conditions, the results indicate that cave versus open-air contexts are important in this region in terms of taphonomy.

There are three important implications concerning taphonomic histories in open air and cave contexts made clear through this study. First, there is an important loss of skeletal material in the early stages of depositions in both contexts, which suggests that remains that become part of the archaeological record may only constitute a small proportion of the originally deposited assemblage. Second, differences in animal activity between assemblages in these different contexts were observed. Carnivores were more impactful in open air contexts, while rodents were more influential in caves.

Third, it was observed in both contexts contrary to what was expected, that vertical and horizontal displacement of skeletal remains occurred. The extent 
of horizontal and vertical movement of bone varied by context; however, this observation needs to be tested via longer temporal experiments. The actualistic studies presented in this paper are part of a broader taphonomic investigation that includes not only short term observations, but also longitudinal actualistic studies of taphonomic histories of assemblages comprising the remains of large mammals (Otaola 2013). These longitudinal studies carried out in different habitats of the Rio Salado valley demonstrate additional differences in displacement of skeletal remains in the different contexts. At rock shelters and caves, the probability of vertical mixing of material is higher, due to the action of rodents and the horizontal limits of the caves. At open air sites, carnivores are an active agent that modify the composition of the assemblages and cause horizontal displacement of bones (Otaola 2013). The results of this actualistic study help to understand archaeological chronological patterns observed in sites from this region, such as inverted dates in caves, which has been observed at Cueva Arroyo Colorado (Lagiglia et al. 1994), Cueva Salamanca and Palulo Cave (Otaola and Llano in press). In addition, rodent remains tend to be common in cave sites but not in open air sites, but carnivore remains occur in both contexts (Otaola 2013).

\section{Acknowledgments}

Steve Wolverton helped improve the English and the content of this paper. Adolfo Gil, Gustavo Neme, and Luis Borrero helped develop the methodology and interpret the results of the actualistic experiments carried out in southern Mendoza. Two anonymous reviewers provided constructive comments that improved the paper. The work presented here was supported by CONICET doctoral and post-doctoral fellowships.

\section{Declarations}

Permissions: Not applicable.

Sources of funding: CONICET.

Conflicts of interest: None declared.

\section{References}

Behrensmeyer, A. K. 1978. Taphonomic and Ecologic Information from Bone Weathering. Paleobiology 4:150-162.

Binford, L.1981. Bones: Ancieint Men and Modern
Myths. Academic Press, London.

Bocek, B. 1986. Rodent Ecology and Burrowing Behaviour: Predicted effects on archaeological Site Formation. American Antiquity 51:589-603.

Borrero, L. A. 2002. Arqueología y Biogeografía Humana en el Sur de Mendoza (Comentario crítico). In Entre Montañas y desiertos: arqueología del sur de Mendoza, edited by A. F. Gil and G. Neme, pp. 194-202. Buenos Aires, Sociedad Argentina de Antropología, Buenos Aires.

Blumenschine, R. J. and C. W. Marean. 1993. A Carnivore's View of Archaeological Bone Assemblages. In From Bones to Behavior. Ethnoarchaeological and Experimental Contributions to the Interpretation of Faunal Remains, edited by J. Hudson, pp. 272-300. Center for Archaeological Investigations, Occasional Paper 21. Southern Illinois University at Carbondale, Carbondale, IL.

Cabrera, A. L. 1971. Fitogeografía de la República Argentina. Boletin de la Sociedad Argentina de Botánica 14:1-42.

Corbat, M., A. F. J. Zangrando and A. Gil. 2009. El Estudio de Restos de Peces en Conjuntos Arqueológicos del Sur de Mendoza. In Arqueología de Patagonia: una mirada desde el último confin, edited by M. Salemme, F. Santiago, M. Álvarez, E. Piana, M. Vázquez and E. Mansur, pp. 717-727. Editorial Utopías, Ushuaia.

Durán, V. 1991. Estudios de Perturbación por Roedores del Género Ctenomys en un Sitio Arqueológico Experimental. Revista de Estudios Regionales 7:7-31.

Efremov, I. A. 1940. Taphonomy: A New Branch of Paleontology. Pan American Geologist 74:81-93

Erlandson, J. M. 1984. A Case Study in Faunalturbation: Delineating Effects of the Burrowing Pocket Gopher on the Distribution of Archaeological Material. American Antiquity 49:785-790.

Fernández, F. J. 2012. Microvertebrados del Holoceno de Sitios Arqueológicos en el Sur de Mendoza (República Argentina): Aspectos Tafonómicos y sus Implicancias en la Subsistencia Humana. Doctoral Dissertation. Facultad de Ciencias Naturales y Museo, Universidad Nacional de La Plata.

Fernández P., I. Cruz, A. I. Forlano. 2010. Sitio 37: Una Madriguera de Carnívoro en el Norte de la 
Patagonia Andina (Cholila, Provincia de Chubut, Argentina). In Zooarqueología a Principios del Siglo XXI, Aportes Teóricos, Metodoslógicos y Casos de Estudio, edited by M. A. Gutierrez, M. De Nigris, P. Fernández, M. Giardina, A. Gil, A. Izeta, G. Neme, H. Yacobaccio, pp. 409-417. Buenos Aires.

Giardina, M. A. 2010. El Aprovechamiento de la Avifauna Entre las Sociedades CazadorasRecolectoras del Sur de Mendoza: Un Enfoque Arqueozoológico. Unpublished Doctoral Dissertation. Universidad Nacional de La Plata, facultad de Ciencias Naturales y Museo.

Gifford-Gonzalez, D. 1989. Ethnographic Analogues for Interpreting Modified Bones: Some Cases from East Africa. In Bone Modification, edited by R. Bonnichsen and M. H Sorg, pp. 179-246. Center for the Study of the First Americans, Institute for Quaternary Studies, University of Maine, Orono, ME.

Gifford-Gonzalez, D.1 991. Bones Are Not Enough: Analogues, Knowledge, and Interpretive Strategies in Zooarchaeology. Journal of Anthropological Archaeology 10:215-254.

Gil, A. 2006. Arqueología de La Payunia. BAR International Series 1477. Archaeopress, Oxford.

Haynes, G. 1980. Evidence of Carnivore Gnawing on Pleistocene and Recent mammalian Bone. Paleobiology 6:341-351.

Haynes, G. 1983. Frequencies of Spiral and GreenBone Fractures on Ungulate Limb Bones in Modern Surface Assemblages. American Antiquity 48:102-114.

Hodder, I. 1982. Symbols in Action. Ethnoarchaeological Studies of Material Culture. Cambridge University Press, Cambridge, MA.

Lagiglia, H. A, G. Neme and A. Gil 1994. Investigaciones Arqueológicas en la Cueva Arroyo Colorado (Malargüe-Mendoza). In Actas y memorias del XI Congreso Nacional de Arqueología Argentina (Segunda parte), edited by H. Lagiglia, pp. 119-120, San Rafael, Mendoza.

Lyman, R. L 1994. Vertebrate Taphonomy. Cambridge University Press, Cambridge, MA.

Marean, C. 1995. Of Taphonomy and Zooarchaeology. Evolutionary Anthropology 4: 64-72.
Martin F. 1998. Madrigueras, Dormideros y Letrinas. In Arqueología de la Patagonia Meridional: Proyecto Magallania, edited by L. A. Borrero, pp. 73-96. Ediciones Búsqueda de Ayllu, Concepción del Uruguay.

Mondini, N. M. 1995 Artiodactyl Prey Transport by Foxes in Puna Rock Shelters. Current Anthropology 36:520-524.

Mondini, N. M. 2003a. Formación del Registro Arqueofaunístico en Abrigos Rocosos de la Puna Argentina: Tafonomía de Carnívoros. Unpublished Dissertation, Facultad de Filosofía y Letras, Universidad de Buenos Aires.

Mondini, N. M. 2003b. Modificaciones Óseas por Carnívoros en la Puna Argentina: Una Mirada Desde el Presente a la Formación del Registro Arqueofaunístico. Mundo de Antes 3:87-108.

Neme G. 2007. Cazadores-recolectores de altura en los Andes meridionales: el alto valle del río Atuel. British Archaeological Reports International Series, 1591. Archaeopress, Oxford.

Neme, G., V. Durán and A. Gil. 1995. Análisis Arqueofaunístico del Sitio Cueva de Luna (Malargüe-Mendoza, Argentina). In Actas del XIII Congreso Nacional de Arqueología Chilena. Hombre y Desierto 9:363-370, Antofagasta, Chile.

Neme G. and A. Gil. 2008. Faunal Exploitation and Agricultural Transitions in the South American Agricultural Limit. International Journal of Osteoarchaeology 18:293-306.

Neme G., A. Gil and V. Durán. 1999. El Registro Arqueofaunístico del Alero Puesto Carrasco (Malargüe-Mendoza). Soplando el Viento... Actas de las Terceras Jornadas de Arqueología de la Patagonia, pp. 491514.

Olson, E. C. 1980. Taphonomy: It's History and Role in Community Evolution. In Fossils in the Making. Vertebrate Taphonomy and Paleoecology, edited by A. K. Behrensmeyer and A. P. Hill, pp. 5-19. University of Chicago Press, Chicago.

Otaola, C. 2013. Zooarqueologia en la Cordillera del Sur de Mendoza: un Enfoque Tafonómico. Unpublished Doctoral dissertation. Facultad de Filosofía y Letras, Universidad de Buenos Aires.

Otaola, C., M. Giardina, M. Corbat and F. J. Fernández. 2012. Zooarqueología en el Sur de Mendoza: 
Integrando Perspectivas Zooarqueológicas en un Marco Biogeográfico. Paleobiogeografía en el Sur de Mendoza, edited by A. Gil and G. Neme. Sociedad Argentina de Antropología, Buenos Aires.

Otaola, C. and C. L. Llano. In press. Consumo de Vegetales y Animales en el Sur de Mendoza: el Caso del Sitio Cueva Palulo. Intersecciones en Antropología.

Roig, V. G. 1972. Esbozo general del poblamiento animal en la Provincia de Mendoza. Boletín de la Sociedad Argentina de Botánica 8 (Suppl.):81-88.
Simpson, G. 1970. Uniformitarianism: An Inquiry into Principle, Theory, and Method in Geohistory. In Essays in Evolution and Genetics in Honor of Theodosius Dobzhansky, edited by M. K. Hecht and W. C. Steere, pp. 43-96. Appleton-Century-Grofts, New York.

\section{Biosketch}

Clara Otaola is a post-doctoral researcher for CONICET, at the Museo de Historia Natural de San Rafael who specializes in zooarchaeology of western Argentina. 